\title{
ВПЛИВ СТРУКТУРНИХ ДЕФЕКТІВ НА ЕКСИТОННУ ФОТОЛЮМІНЕСЦЕНЦІЮ ПЕНТАЦЕНУ
}

\author{
Ю.П. ПИРЯтИнСЬКИЙ, М.В. КУРИК
}

Удк 538.958, 539.2 Інститут фізики НАН України

(c)2011 (Просn. Науки, 46, Київ 03028)

Досліджено екситонні спектри відбиття, поглинання і фотолюмінесценції монокристалів і полікристалічних плівок пентацену в інтервалі температур 4,2-296 К. Встановлено істотний вплив структурних дефектів, які виникають при фазових перетвореннях, на екситонні спектри пентацену. Розглянуто механізми виникнення фотолюмінесценції в монокристалах і кристалічних плівках пентацену.

\section{1. Вступ}

Молекулярні кристали лінійних поліаценів, до яких відноситься пентацен, характеризуються закономірним зростанням величини міжмолекулярної взаємодії в $a b$-площині кристала при збільшенні числа бензольних кілець у молекулі [1] і слабкою міжплощинною взаємодією. За допомогою досліджень оптичних властивостей молекулярних кристалів (спектри поглинання, відбиття, фотолюмінесценції) при різних температурах добре вивчено енергетичну структуру монокристалів антрацену [2] і тетрацену [3-5]. Кристали пентацену в цьому плані вивчено значно гірше, особливо це стосується природи фотолюмінесценції кристалічно досконалих монокристалів. Для з'ясування природи фотолюмінесценції кристалічного пентацену становить інтерес вивчення його оптичних характеристик у широкому інтервалі температур. 3 точки зору фізики екситонів у кристалах лінійних поліаценів науковим інтересом є дослідити за допомогою низькотемпературної спектроскопії екситонні спектри монокристалів пентацену (п'ять бензольних кілець). Для цього поліацену характерним є максимальна величина давидівського розщеплення екситонів і фазовий перехід структури гратки (моноклінна- триклінна симетрія) та дефекти структури, які суттєво впливають на екситонні спектри пентацену.

Метою даної роботи було провести детальне вивчення впливу дефектів кристалічної структури монокристалів на прояв екситонів з оптичних спектрів пентацену. Досліджено екситонні спектри фотолюмінесценції (ФЛ), відбиття (R) і поглинання (kd) кри- сталічного пентацену в широкому інтервалі температур $(T=4,2-296 \mathrm{~K})$. Зразки у вигляді вільно закріплених товстих монокристалів і тонких моно- і полікристалічних плівок пентацену, що знаходяться на оптичному контакті з кварцовою підкладкою. Отримані результати пояснюються на основі особливостей кристалічної структури монокристалів та тонких полікристалічних плівок пентацену, чутливих до деформації кристалічної гратки при зміні температури. Обговорено природу збуджень (вільні і локалізовані на структурних дефектах молекулярні і з перенесенням заряду екситони) спостережуваних смуг ФЛ.

\section{2. Методика експерименту}

Монокристали пентацену вирощували методом сублімації в атмосфері гелію при температурі 530-550 K 3 добре очищеного пентацену. Початковий пентацен піддавали очищенню багатократною перекристалізацією. У процесі росту виходили монокристали завтовшки від 100 нм до 50 мкм 3 добре розвиненою $a b$-площиною. Для більшості монокристалів товщиною $d=20-50$ мкм одна $3 a b$-площин кристала виходила дзеркальною, а друга - матовою, що пов'язано з особливостями росту кристалів. Кристалічні плівки пентацену отримували термічним напиленням у вакуумі $10^{-5}-10^{-6}$ мбар на кварцову підкладку при температурі 296 К. Оптичні спектри поглинання показують, що нанесені шари пентацену складаються з плоских, щільно упакованих кристалітів, $a b$-площини яких орієнтовані переважно паралельно поверхні підкладки. Спектри відбиття R монокристалів пентацену вимірювалися в поляризованому світлі від $a b$-площини кристала при куті падіння світла на неї $\sim 15^{\circ}$. Для В-поляризованої компоненти спектра $\mathrm{R}$ сигнал виставляли по максимуму інтенсивності відбиття від $a b$-площини кристала. Спектри поглинання кристалічного пентацену вимірювалися при нормальному куті падіння природного або лінійно-поляризованого світла на $a b$-площину кристала. При вимірюваннях спектрів поглинання тонких 
$(d=100$ нм) монокристалів пентацену в поляризованому світлі кристал розташовували між двома схрещеними поляризаторами і орієнтували на нульовий сигнал по світлу, що пройшло в області прозорості пентацену. Після цього поляризатори виставлялися для вимірювання спектрів поглинання світла, поляризованого паралельно, а потім і перпендикулярно до $b$-осі кристала ( $B$ - і $A$-поляризації відповідно).

Спектри ФЛ кристалічного пентацену досліджували у стаціонарному режимі і з використанням методики наносекундного розділення в часі. У другому випадку для збудження ФЛ використовували: азотний лазер (довжина хвилі випромінювання $\lambda_{e}=337,1$ нм, тривалість збуджуючого імпульсу $t_{I}=9 \mathrm{Hc}$, потужність випромінювання в імпульсі $N=3 \mathrm{kB}$, частота повторення імпульсів $f=80$ Гц) і друга гармоніка випромінювання $\mathrm{Nd}$ :YAG лазера $\left(\lambda_{e}=532 \mathrm{нм}\right.$, $t_{I}=10 \mathrm{Hc}, N=100 \mathrm{kBт}, f=50$ Гц). Реєстрацію розділеної в часі ФЛ вели за допомогою стробоскопічної системи $[3,4]$ з різною часовою затримкою $t_{d}$ щодо імпульсу лазерного збудження. Спектри ФЛ кристалічного пентацену реєстрували в інтервалі часу 0-1 нс. Як спектральний прилад використовували світосильний гратчастий монохроматор МДР-12. Спектральна ширина щілини при вимірюванні спектрів ФЛ становила 0,2-0,4 нм. При реєстрації ФЛ у стаціонарному режимі кристали збуджувалися Не-Cd лазером потужністю $40 \mathrm{mB}$ т $\left(\lambda_{e}=\right.$ 441, 6 нм). Реєстрацію ФЛ вели в режимі підрахунку фотонів.

\section{3. Експериментальні результати та їх обговорення}

Дослідження ФЛ проведено в інтервалі температур 4,2-300 К. ФЛ спостерігалася для монокристалів пентацену товщиною $d=20-50$ мкм і полікристалічних плівок ( $d=100$ нм), отриманих термічним напиленням у вакуумі. Для монокристалів пентацену $(d=20-50$ мкм $)$ ФЛ збуджувалася з боку дзеркальної поверхні випромінюванням від $\mathrm{He}-\mathrm{Cd}$ лазера $\lambda_{e}=441,6$ нм і реєструвалася в режимі підрахунку фотонів. При збудженні монокристалів пентацену $(d=0,1-50$ мкм $)$ випромінюванням від азотного лазера нам не вдавалося зареєструвати ФЛ. Для кристалічних плівок пентацену, отриманих термічним напиленням у вакуумі, ФЛ можна було спостерігати в інтервалі температур 4,2-296 K при збудженні азотним або $\mathrm{Nd}$ :YAG лазером.

На рис. 1 наведено спектри ФЛ монокристала пентацену $(d=20$ мкм $)$ при збудженні $\mathrm{He}-\mathrm{Cd}$ лазером.

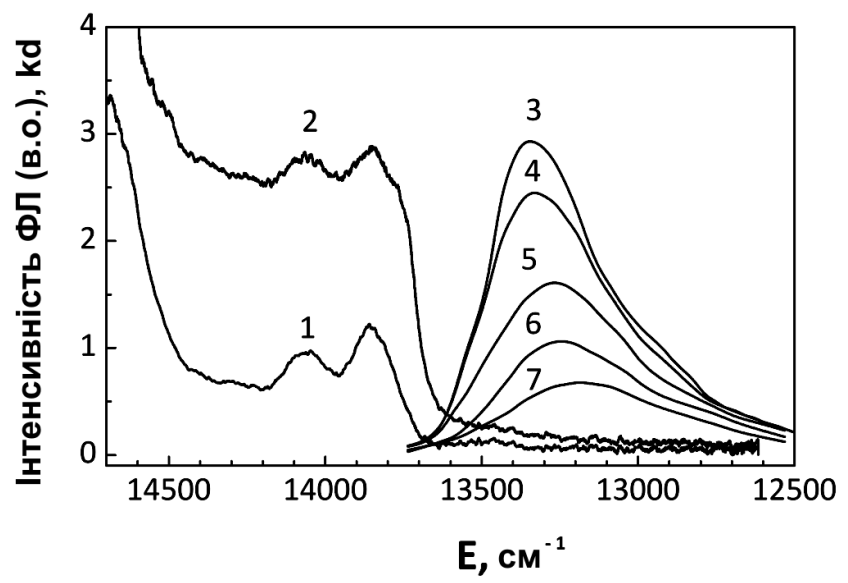

Рис. 1. Спектри поглинання $\mathrm{kd}$ (для $B$ - (2) i $A$ - (1) поляризацій) і фотолюмінесценції ФЛ (3-7) монокристала пентацену товщиною $d=20$ мкм при температурах $T=4,2$ (1-3), 14 (4), 20 (5), 25 (6) і 30 (7) К. Спектри ФЛ виміряно від дзеркальної поверхні, $\lambda_{e}=441,6 \mathrm{Hм}$

Для цього монокристала пентацену ФЛ спостерігалася в інтервалі температур 4,2-65 K. При 4,2 K спектр ФЛ пентацену (рис. 1) є широкою безструктурною смугою з максимумом при $13300 \mathrm{~cm}^{-1}$ і затягнутому в довгохвильовий бік плечем. При підвищенні температури до $17 \mathrm{~K}$ інтенсивність ФЛ істотно не змінювалася. За подальшого підвищення температури інтенсивність ФЛ експоненціально зменшувалася з енергією активації цього процесу $170 \mathrm{~cm}^{-1}$. При $65 \mathrm{~K}$ фотолюмінесценцію пентацену вже неможливо було зареєструвати.

На рис. 1 також наведено спектри поглинання досліджуваного монокристала пентацену в області прозорості кристала при $4,2 \mathrm{~K}$, виміряні для $A$ - і $B$ поляризацій, крива 1 та крива 2 відповідно. Поглинання спостерігалося нижче дна екситонної зони i було частково поляризоване. У спектрі можна виділити смуги з максимумами при 13760, 13850 і 14050 $\mathrm{cm}^{-1}$ для $B$-поляризації і 13850 i $14050 \mathrm{~cm}^{-1}$ для $A$ поляризації кристала.

На рис. 2 наведено спектри відбиття для $B$ поляризації вільно закріпленого монокристала пентацену $(d=20$ мкм), виміряні від дзеркальної поверхні в інтервалі температур 1,85-250 K і спектральній області 14000-15000 см ${ }^{-1}$. Для $B$-компоненти спектра відбиття при $T=1,85 \mathrm{~K}$ спостерігається інтенсивна смуга 3 довгохвильовим максимумом при $14460 \mathrm{~cm}^{-1}$. Звертають на себе увагу також провали з мінімумами при 14490 i $14600 \mathrm{~cm}^{-1}$, які, як й у випадку антрацену [6] і тетрацену $[3,5]$, можна пов'язати із збудженням поверхневих екситонів. При підвищенні температури 


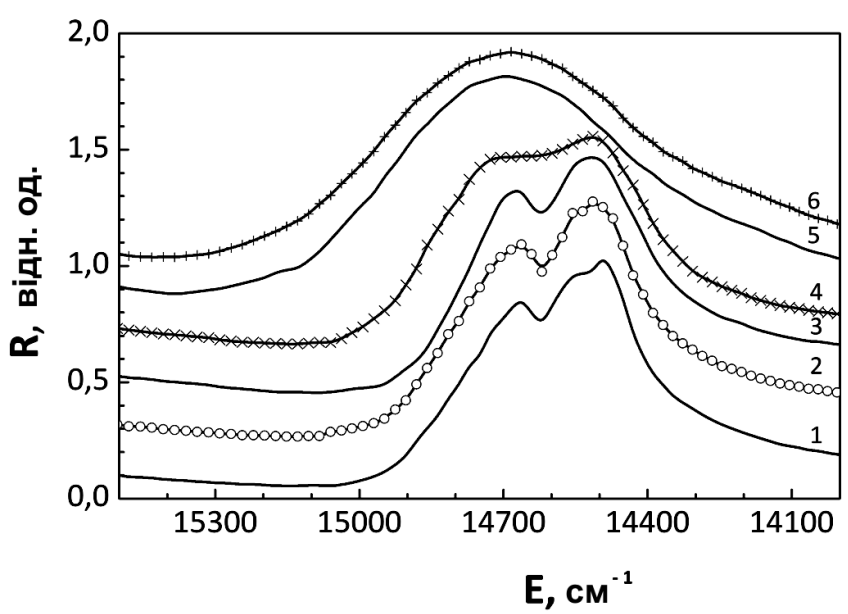

Рис. 2. Спектри відбиття для $B$-поляризацї вільно закріпленого монокристала пентацену при різних температурах: $T=1,85$ (1), 4,2 (2), 10 (3), 43 (4), 200 (5) i 250 (6) K; $d=20$ мкм

до $43 \mathrm{~K}$ ці провали замиваються і при вищій температурі вони пропадають.

На основі наведених вище екситонних спектрів відбиття можна визначити положення дна екситонної зони в монокристалах пентацену за методом, описаним у роботі [6]. Положення довгохвильового максимуму при $14460 \mathrm{~cm}^{-1}$ можна ототожнити з положенням 0-0 переходу об'ємного $b$-екситона.

У спектрі відбиття монокристалів пентацену, виміряних від матової поверхні при $1,85 \mathrm{~K}, B$-смуга відбиття безструктурна і в ній поверхневі екситони не спостерігаються. Іншою особливістю низькотемпературних спектрів відбиття є те, що при температурі вище $170 \mathrm{~K}$ спостерігається стрибкоподібний зсув спектрів відбиття для $A$ - і $B$-компонент в короткохвильовий бік. Для $B$-компоненти спектра відбиття цей зсув близький до $180 \mathrm{~cm}^{-1}$. Виміряні значення максимумів довгохвильових смуг екситонного відбивання при температурах 1,85, 170 і $296 \mathrm{~K}$ відповідно, рівні: для $B$-поляризації - 14460, 14640 і $14720 \mathrm{~cm}^{-1}$; для $A$-поляризації - 15640, 15740 і $15750 \mathrm{~cm}^{-1}$.

Внаслідок триклінної структури кристалів пентацену електронні переходи в них необов'язково повинні бути строго поляризовані уздовж $b$ - і $a$-осей кристала. Величина резонансного розщеплення для монокристалів пентацену, обчислена як різниця енергій $a$ - і $b$-екситонних зон для вказаних вище температур становить 1180, 1100 і $1030 \mathrm{~cm}^{-1}$. Для монокристалів антрацену і тетрацену значення резонансного розщеплення екситонних зон при низьких температурах становить 225 [6] і 960 [3] $\mathrm{cm}^{-1}$. У спектрах відбиття монокристалів тетрацену спостерігався стрибкоподі-

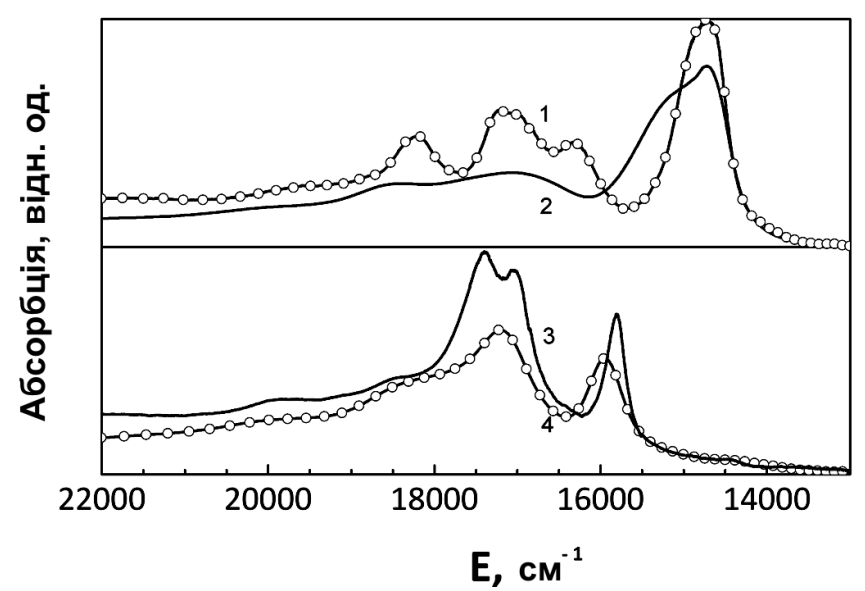

Рис. 3. Спектри поглинання монокристалічної плівки пентацену товщиною $d=100$ нм, що знаходиться на оптичному контакті з кварцовою підкладкою, для $B$ - $(1,2)$ і $A$ - $(3,4)$ поляризацій при 4,2 (1, 3) і $296(2,4) \mathrm{K}$

бний зсув екситонних спектрів відбиття при низьких температурах, що зв'язувалось із структурним фазовим переходом першого роду $[3,5]$ в них. Враховуючи близький характер кристалічної структури кристалів тетрацену і пентацену при 296 K (обидва кристали триклінні), для останнього також можна припустити існування двох модифікацій - високо- і низькотемпературної. Для кристалів тетрацену показано [3], що фазовий перехід в ньому пов'язаний зі зміною симетрії кристала і викликаний збільшенням внутрішнього тиску у кристалі унаслідок його стиснення при пониженні температури. Для кристалів пентацену також [7] спостерігалася зміна кристалічної структури під тиском, що фіксувалося по зсуву екситонних смуг. Тому можна вважати, що стрибкоподібний зсув смуг екситонних спектрів відбиття у кристалах пентацену при $170 \mathrm{~K}$ пов'язаний із структурним фазовим переходом у ньому. У роботі [8], на основі даних електронної дифракції у тонких шарах пентацену, висловлено припущення, що при низьких температурах у пентацені утворюється більш щільно упакована гратка.

На рис. 3 наведено спектри поглинання монокристалічної плівки пентацену товщиною $d=100$ нм, що знаходиться на оптичному контакті з кварцовою підкладкою. Спектри поглинання виміряні для $B$ - (криві 1, 2) і $A$-поляризацій (криві 3, 4) при 4,2 K (криві 1, 3) і $296 \mathrm{~K}$ (криві 2, 4). Відмінності у спектрах поглинання монокристалічних плівок пентацену при кімнатній i 4,2 K температурах також, як і у спектрах відбиття, можна пов'язати з фазовими перетвореннями у них.

У спектрах поглинання пентацену, виміряних в області першого синглетного $S_{1}$ електронного пере- 
ходу при 4,2 K (криві 1, 3), спостерігається багато смуг. Найбільш інтенсивні смуги спектрів поглинання мають максимуми при 14710, 16320, 17000, 17220, 18220, 18780, 19700, $21600 \mathrm{~cm}^{-1}$ для $B$-поляризації (крива 1) i 15810, 17040, 17400, 18400, 19100, 19900, $21100 \mathrm{~cm}^{-1}$ - для $A$-поляризації (крива 3). При нагріванні монокристалічних плівок пентацену до $296 \mathrm{~K}$ спектри поглинання для $B$ - і $A$-поляризацій зміщуються в короткохвильовий бік, і смуги розширюються. Найбільш інтенсивні смуги спектрів поглинання при 296 К мають максимуми при 14710, 14920, $17070,18420,19800 \mathrm{~cm}^{-1}$ для $B$-поляризації (крива 2) i $15950,17200,18300,20000 \mathrm{~cm}^{-1}$ для $A$-поляризації (крива 4). Із зіставлення положення смуг поглинання при 4,2 і $296 \mathrm{~K}$ для $A$-поляризації видно, що довгохвильова смуга спектра змістилася в короткохвильовий бік на $180 \mathrm{~cm}^{-1}$. Для $B$-поляризації спектра поглинання можна спостерігати зсув центра тяжіння довгохвильової смуги. Максимум довгохвильової смуги поглинання, як і у випадку низькотемпературного спектра (крива 1) знаходиться при $14710 \mathrm{~cm}^{-1}$, а 3 короткохвильового боку цієї смуги є плече при $14920 \mathrm{~cm}^{-1}$. Значне розширення смуги в короткохвильовий бік пов'язане з тим, що тонкий кристал пентацену знаходиться на оптичному контакті з кварцовою підкладкою. Внаслідок цього область пентацену, яка контактує 3 кварцом, деформована. Це приводить до утворення у цій області кристала підвищеного тиску і виникнення низькотемпературної модифікації пентацену з максимумом поглинання при $14710 \mathrm{~cm}^{-1}$. Плече при 14920 $\mathrm{cm}^{-1}$ можна пов'язати з присутністю у монокристалічній плівці пентацену високотемпературної модифікації, яка переважає у плівці з боку вільної поверхні. У спектрах відбиття таких монокристалічних плівок, виміряних від вільної поверхні і що контактує з кварцовою підкладкою, нами спостерігалися відмінності, які також можна пов'язати 3 деформацією кристалічної гратки пентацену у підкладки. Пониження температури до 4,2 K приводить до переходу всього кристала в низькотемпературну модифікацію з максимумом смуги поглинання при $14710 \mathrm{~cm}^{-1}$.

Дослідження спектрів поглинання монокристалічної плівки $(d=100$ нм), що знаходиться на оптичному контакті з кварцовою підкладкою, і кристалічної плівки такої самої товщини, але отримані термічним напиленням у вакуумі на кварцову підкладку показали, що при вимірюваннях у природному світлі вони подібні. Це відповідає висловленому вище припущенню, що нанесені термічним напиленням на кварц тонкі шари пентацену складаються з плоских, щільно упакованих кристалітів, $a b$-площина яких орі-

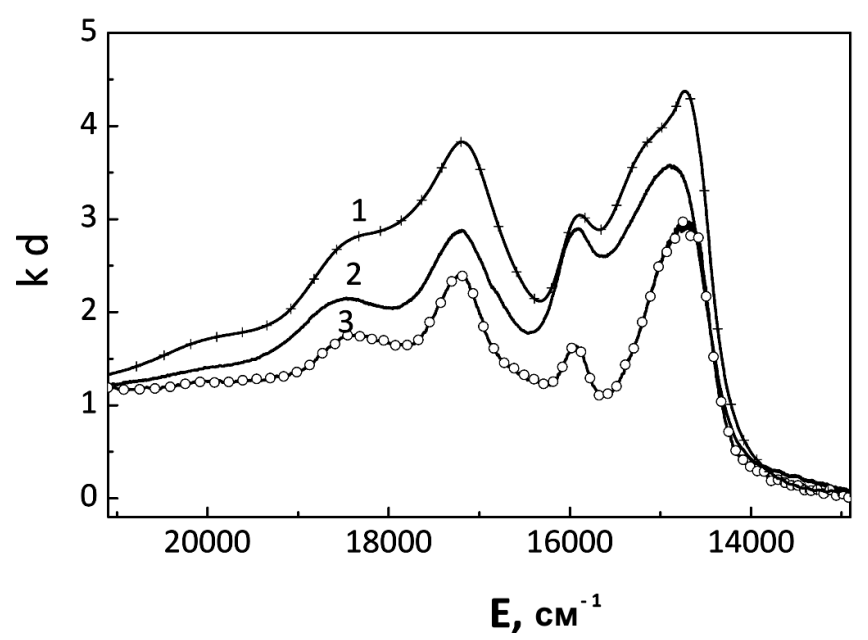

Рис. 4. Спектри поглинання монокристалічної (1) і отриманої термічним напиленням у вакуумі $(2,3)$ плівок пентацену товщиною $d=100$ нм при $T=296$ (1, 2) і 4,2 (2) $\mathrm{K}$, виміряні у природному світлі

єнтована переважно паралельно поверхні підкладки. На рис. 4 наведено спектри поглинання кристалічної плівки (криві 2, 3) товщиною $d=100$ нм, отриманої термічним напиленням у вакуумі. Спектри виміряні при 296 (2) і 4,2 (3) K. Для порівняння на цьому ж рисунку показано спектр монокристалічної плівки пентацену такої ж товщини (крива 1), що знаходиться на оптичному контакті з кварцовою підкладкою. Спектри поглинання монокристалічної плівки (крива 1) пентацену виміряні при $296 \mathrm{~K}$ у природному світлі. У цьому спектрі поглинання можна виділити смуги з максимумами при 14710, 15070,15900, 17200 i $18390 \mathrm{~cm}^{-1}$. Для полікристалічної плівки пентацену при $296 \mathrm{~K}$ (крива 2) у спектрі поглинання спостерігаються смуги з максимумами при 14890, 15910, 17200, $18500 \mathrm{~cm}^{-1}$, а при 4,2 K (крива 3) - 14710, 15940, 17190 i $18380 \mathrm{~cm}^{-1}$.

3 рис. 4 видно, що у спектрах поглинання як монокристалічних плівок пентацену, що знаходяться на оптичному контакті з кварцовою підкладкою, так і отриманих термічним напиленням на кварцову підкладку при кімнатній температурі виявляються високотемпературна і низькотемпературна модифікації пентацену. Наявність низькотемпературної модифікації пентацену у кристалічних плівках пентацену при кімнатній температурі можна пов'язати з взаємодією приповерхневого шару пентацену з кварцовою підкладкою. Очевидно, що у приповерхневому шаpi пентацену, який межує з підкладкою, виникають області підвищеного тиску і в них відбувається структурний фазовий перехід. Нижче за точку фазового 


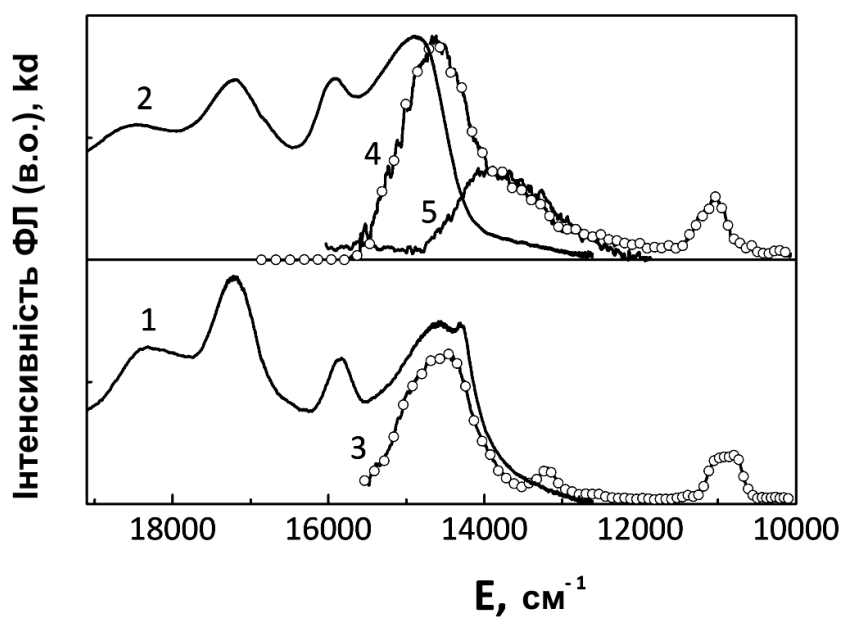

Рис. 5. Спектри поглинання $\mathrm{kd}(1,2)$ i фотолюмінесценції ФЛ термічно напиленої плівки пентацену товщиною $d=100 \mathrm{нм}$ при температурах $T=4,2(1,3)$ i $296(2,4,5) \mathrm{K} . \lambda_{e}=532 \mathrm{Hм}$ $(3,4)$ i 337,1 нм (5)

переходу в екситонних спектрах поглинання виявляється в основному низькотемпературна модифікація пентацену.

На рис. 5 показано спектри ФЛ кристалічної плівки пентацену товщиною 100 нм, отриманої термічним напиленням у вакуумі. Спектри ФЛ виміряні з наносекундним часовим розділенням $\left(t_{d}=0-1\right.$ нс) при 296 $(4,5)$ і 4,2 (3) К. Спектри ФЛ (3, 4) отримані при збудженні кристалічних плівок пентацену Nd:YAG лазером $\left(\lambda_{e}=532\right.$ нм). У спектрі ФЛ кристалічної плівки при $4,2 \mathrm{~K}$ можна виділити смуги з максимумами при 14500, 13200 і $10900 \mathrm{~cm}^{-1}$. При підвищенні температури до 296 К спектр ФЛ (4) зміщувався в короткохвильовий бік і в ньому можна виділити смуги з максимумами при 14610, 13950 і 11070 см$^{-1}$. Смуга ФЛ 13950 $\mathrm{cm}^{-1}$ при кімнатній температурі корелює із смугою (5), отриманою при збудженні ФЛ азотним лазером. Спектр ФЛ (5) плівки пентацену спостерігався при кімнатній температурі і збуджувався азотним лазером $\left(\lambda_{e}=337,1\right.$ нм $)$ з боку кварцової підкладки. На цьому ж рисунку наведено спектри поглинання досліджуваної плівки пентацену при 4,2 (1) і 296 (2) К.

Квантовий вихід ФЛ у низці кристалів лінійних поліаценів (нафталін, антрацен, тетрацен, пентацен) істотно залежить від синглет-триплетного розщеплення [9]. Для кристалів антрацену, у якого розщеплювання станів $S_{1}-T_{1}$ максимальне, квантовий вихід ФЛ максимальний - 0,95. Квантовий вихід ФЛ кристалів тетрацену при кімнатній температурі $\sim 0,002$, а для молекули - 0,21. Для монокристалів пентацену, де це розщеплювання найменше, згідно з літератур- ними даними [9], квантовий вихід ФЛ близький до нуля. Передбачається у роботі [9], що це пов'язано з високою ефективністю розпаду синглетного екситона на два триплетних. Водночас молекули пентацену, що знаходяться у кристалічній матриці ароматичних вуглеводів, досить добре люмінесцюють [10]. Така відмінність у фотолюмінесцентних властивостях кристалів і ізольованих молекулах пентацену в даний час не знайшла задовільного пояснення і вимагає подальших досліджень.

$\mathrm{У}$ роботі [11] було показано, що молекули пентацену, впроваджені в матрицю кристалів антрацену, вище за поріг розчинності утворюють кластери. Передбачалося, що ці кластери - нанокристали або блоки з молекул пентацену на зовнішній поверхні чи дислокаціях монокристала антрацену. Нижче за межу розчинності пентацену в кристалах антрацену низькотемпературні спектри ФЛ матриці антрацену близькі до спектрів чистого антрацену. У спектрі ФЛ, що добре розділяється, видно також низку вузьких піків емісії молекул пентацену з чисто електронною смугою $16395 \mathrm{~cm}^{-1}$. При концентраціях пентацену, вищих за поріг розчинності смуги емісії антрацену розширюються, а у спектрах ФЛ пентацену поблизу чистоелектронного молекулярного переходу з'являється широкий безструктурний фон, зумовлений ФЛ кластерів пентацену.

$\mathrm{У}$ роботі [12] повідомлялося про ФЛ полікристалічних плівок пентацену з підкладками з аеросила і ситала при 77 і $300 \mathrm{~K}$. Спектр ФЛ цих плівок подібний до спектра ФЛ твердого розчину пентацену в нафталіні і складається із смуг 15500 і $16500 \mathrm{~cm}^{-1}$. Виходячи 3 цього, було зроблено припущення, що ФЛ полікристалічних плівок пентацену пов'язана з наявністю в них аморфної фази. Виміряний у роботі час життя ФЛ молекул пентацену при $293 \mathrm{~K}$ в полікристалічній плівці становив 3,3 нс, а у твердому розчині нафталіну - 10,3 нс. Відмінність між часом життя ФЛ, на думку авторів, пояснюється тим, що у твердих розчинах пентацену в нафталіні світять окремі молекули пентацену (електронний перехід ${ }^{1} A_{1 g^{-}}{ }^{1} B_{2 u}$ ), а в плівках - структурно-деформовані комірки кристалітів.

При високих температурах можливе термічне розкладання молекул пентацену. Не виключено, що у процесі вирощування кристалів методом сублімації або при термічному напиленні плівок у вакуумі, окремі молекули пентацену можуть термічно розкладатись і бути центрами випромінювання. Виходячи 3 цього, у роботі [13] досліджено вплив високих температур на спектри ФЛ кристалічного пентацену. Досліджена ФЛ монокристалів, отриманих в умовах 
термічного розкладання молекул пентацену. При вирощуванні монокристалів пентацену було встановлено, що якщо температуру в кристалізаторі підняти вище $620 \mathrm{~K}$, то в окремих молекулах пентацену відбуваються незворотні перетворення. Кристали, вирощені при $T>620 \mathrm{~K}$, на відміну від темно-синіх монокристалів пентацену, були безбарвні або мали рожевий відтінок. Як відомо з [14], при $T>620 \mathrm{~K}$ можливе термічне розкладання пентацену з утворенням дигідропентацену. Дослідження спектрів ФЛ [13] термічно змінених кристалів пентацену при 4,2 K показали, що вони складні. У цьому спектрі можна виділити декілька спектральних областей, які корелюють 3 випромінюванням молекулярного нафталіну, антрацену, пентацену і широкі безструктурні смуги нанокластерів пентацену. У роботі [15] повідомлялося про ФЛ кристалічних нанокластерів ультратонких (2,8-7 нм) плівок пентацену при 77 К. У спектрах ФЛ нанокластерів пентацену спостерігалися дві смуги 14840 і $15650 \mathrm{~cm}^{-1}$, зумовлені емісією френкельовських екситонів з величиною давидовського розщеплення $810 \mathrm{~cm}^{-1}$. Положення вказаних смуг ФЛ залежало від товщини плівки і розмірів нанокластерів. При зменшенні товщини плівки спектр ФЛ дещо зміщувався в короткохвильовий бік.

Якщо виходити з припущення, що відсутність ФЛ у кристалах пентацену пов'язана з високою швидкістю поділу $S_{1}$ синглетного екситона на два триплетних [9], то при низьких температурах, за відсутності резонансного збігу енергій синглетного і двох триплетних екситонів, швидкість поділу зменшиться і можуть виникнути сприятливі умови для спостереження ФЛ монокристалів пентацену.

Для кристалів пентацену у ряду лінійних поліаценів спостерігається найбільша відстань між abплощинами, яка становить 1,6 нм. Такі кристали характеризуються сильною резонансною взаємодією в $a b$-площині і дуже слабкою взаємодією у напрямку $c$-осі кристала. Виходячи із слабкої взаємодії між $a b$ площинами молекулярні екситони у кристалах пентацену можна вважати двовимірними. При дослідженні молекулярних екситонів в ідеальних одновимірних і двовимірних кристалах виникає низка специфічних особливостей. У роботі [16] обчислювали час життя екситонів по відношенню до випромінювального розпаду. Для одновимірних екситонів воно виявилося таким:

$\tau_{\mathrm{ex}}=\tau_{0} 4 r / 3 \lambda$,

де $\tau_{0}=3 h^{4} c^{3} 4 E(0)^{3} \mathbf{d}^{2}$ - час життя збудження з енергією $E(0)$ в ізольованій молекулі, $r$ - відстань між молекулами, $\lambda$ - довжина хвилі випромінювання, $\mathbf{d}$ дипольний електричний момент, $c$ - швидкість світла. Оскільки $r / \lambda \sim 10^{-3}$, то $\tau_{\text {ex }}$ в одновимірному молекулярному ланцюзі, по відношенню до випромінювального розпаду, у тисячу разів менше за $\tau_{0}$. Для двовимірного кристала час життя екситона близький $(r / \lambda)^{2} \sim 10^{-14}-10^{-15}$ с, тобто стає порівнянним 3 періодом обертання електрона у кристалі і часом внутрішньомолекулярної коливальної релаксації. Величина $1 / \tau_{\text {ex }}$ визначає імовірність збудження екситона фотоном. Тому для двовимірних кристалів імовірність збудження екситонів в $10^{5}-10^{6}$ разів перевищує імовірність збудження $1 / \tau_{0}$ вільної молекули. При високих коефіцієнтах поглинання в молекулярних кристалах спостерігається висока ступінь взаємодії збудження з полем світлової хвилі і утворюються поляритони. Коли взаємодія між екситонами i полем світлової хвилі перевершує по величині взаємодію екситонів з будь-якими іншими дезактивуючими коливаннями кристала, екситони повертають свою енергію електромагнітному полю світла. Експериментально для пентацену це проявляється у великих коефіцієнтах відбиття при енергіях опромінюючого світла, близьких до енергії $b$-екситона при низьких температурах. Внаслідок цього спостережувана в інтервалі температур 4,2-65 К ФЛ для товстих досконалих монокристалів пентацену може бути пов'язана із багатократним розсіюванням поляритонів у кристалі i захопленням їх через екситонну компоненту структурними дефектами.

Спостережувана температурна залежність ФЛ монокристалів пентацену з максимумом $13300 \mathrm{~cm}^{-1}$ при 17 K характерна для переддимерних станів. Такі стани в низькомолекулярних кристалах, зазвичай, утворюються в областях дислокаційних дефектів. Виходячи із зазначеного, можна припустити, що спостережувана ФЛ пов'язана з областями кристала пентацену, де молекули мають переддимерний стан. Якщо порівняти положення максимуму смуги ФЛ при $4,2 \mathrm{~K}$ 3 енергетичним положенням дна екситонної зони (14460 см $\left.{ }^{-1}\right)$, визначеної по спектрах відбиття для $B$-поляризації (рис. 2), то видно, що найбільш інтенсивна смуга ФЛ має довгохвильове зміщення близько $1160 \mathrm{~cm}^{-1}$. Водночас це зміщення значно більше за енергію активації гасіння фотолюмінесценції при підвищенні температури від 17 до 65 К. У цьому інтервалі температур у спектрах відбиття монокристалів пентацену для $B$-поляризації спостерігається смуга $13460 \mathrm{~cm}^{-1}$, а для $A$-поляризації - $14300 \mathrm{~cm}^{-1}$. Виходячи з цього, можна припустити, що спостережувана ФЛ монокристалів пентацену може бути зумов- 
лена включеннями нової метастабільної поліморфної модифікації пентацену, яка виявляється в інтервалі температур 4,2-65 K у місцях дислокаційних дефектів.

Для молекулярних кристалів типу пентацену, разом із внутрішньомолекулярним каналом безвипромінювальної конверсії коливально-збудженого синглетного екситона, є канали міжмолекулярної релаксації, пов'язані з утворенням іонних станів. При збудженні кристала пентацену поблизу порога власної фотопровідності $\left(E_{g}>2,8\right.$ еВ [17]) спостерігається пряма автоіонізація метастабільного синглетного екситона. При вищих енергіях збудження спостерігається попередня коливальна релаксація до другого $\left(S_{2}, E=3,0 \mathrm{eB}[18]\right)$ збудженого синглетного стану $з$ подальшою автоіонізацією. Квантовий вихід автоіонізації для кристалів пентацену близький до 1 і цим можна пояснити той факт, що при збудженні $\left(\lambda_{e}=337,1\right.$ нм) товстих досконалих монокристалів вище порога фотопровідності ФЛ не спостерігалася.

При збудженні кристалів пентацену нижче порога власної фотопровідності, разом із збудженням молекулярних екситонів, спостерігається пряме збудження екситонів з перенесенням заряду (СТ-екситонів) [19]. Сила осцилятора переходу з перенесенням заряду на найближчі сусідні молекули в кристалах пентацену близька до 0,01. Така велика сила осцилятора СТ-переходів у кристалах пентацену зумовлена змішуванням СТ-екситонів з найближчими по енергіі нейтральними молекулярними екситонами з великою силою осцилятора переходу. СТ-екситони як проміжні стани при фотогенерації також можуть давати внесок в ФЛ. Як видно з наведених на рис. 3 спектрів поглинання монокристалічних плівок пентацену, в них не є видимою характерна для молекул пентацену коливальна повторюваність, відлічена від чисто електронного переходу для $A$ - i $B$ поляризованих спектрів. Такі відхилення у спектрах поглинання можна пов'язати зі значним внеском СТпоглинання в сумарне молекулярне і СТ-екситонне поглинання кристалічного пентацену. Для кристалів пентацену енергія СТ-переходів між сусідніми молекулами в положеннях $(0,0,0)-(1 / 2,1 / 2,0),(0,0,0)-$ $(0,1,0),(0,0,0)-(1,0,0)$, визначена по спектрах електровідбиття [20], дорівнює 2,12; 2,27 і 2,345 еВ відповідно. При збудженні кристала пентацену в цій спектральній області найбільш імовірний $(0,0,0)-(1 / 2,1 / 2,0)$ перехід з найменшою відстанню між молекулами. Після прямого збудження СТ-екситона іде його локалізація з пониженням енергії у кристалах пентацену на 0,3 eB [17]. Для кристалів пентацену найменший за енергією локалізований стан СТ-екситонів знаходитиметься при 1,82 еВ (14680 см $\left.{ }^{-1}\right)$. Локалізація СТекситона на структурному дефекті при низьких температурах також може приводити до спостережуваної нами ФЛ як для товстих, структурно досконалих кристалів, так і для полікристалічних плівок.

Викладений вище матеріал для часу життя екситонів в одновимірних і двовимірних молекулярних кристалах справедливий, якщо характерні розміри цих кристалів немалі у порівнянні з довжиною хвилі випромінювання екситона [16]. Для полікристалічних плівок пентацену характерні розміри кристалітів близько 0,1 мкм, що менше довжини хвилі випромінювання. Отже, для полікристалічних плівок пентацену, де виявляються розмірні ефекти, випромінювальна анігіляція молекулярного збудження може протікати інакше, ніж для масивного досконалого кристала.

3 порівняння спектрів поглинання і ФЛ полікристалічних плівок пентацену можна припустити, що смуги 14500 і $14610 \mathrm{~cm}^{-1}$ можна пов'язати з випромінюванням вільних екситонів у кристалітах пентацену, як у випадку [21]. Смуги 13200 і 13950 см$^{-1}$ зумовлені локалізацією екситонів на структурних дефектах. При цьому, як видно із спектрів ФЛ (4 і 5), найбільший внесок при кімнатній температурі в локалізацію екситонів дають структурні дефекти на межі кристалітів.

\section{4. Висновки}

Виконані комплексні спектральні дослідження особливостей прояву екситонних станів у спектрах відбиття, поглинання і люмінесценції при низьких температурах різних за ступенем досконалості структури монокристалів пентацену дозволили отримати нові дані відносно взаємозв'язку структури кристалів пентацену (монокристали, полікристали) дефектів структури, також і фазових переходів (монокліннатриклінна симетрія) на енергетику екситонів і їх динаміку у спектрах при різних температурах.

Вперше для представлення молекулярних кристалів лінійних поліаценів, пентаценів експериментально встановлено, що величина міжмолекулярної взаємодії, симетрія кристалічної гратки і структурний фазовий перехід (моноклінна-триклінна структура) є основними і специфічними у формуванні кінетики екситонних процесів.

1. А.И. Китайгородский, Молекулярные кристалль (Наука, Москва, 1971). 
2. М.С. Бродин, С.В. Марисова, А.Ф. Прихотько, Экситоны в молекулярных кристаллах (Наукова думка, Киев, 1973), с. 50.

3. J.M. Turlet and M.P. Philpott, J. Chem. Phys. 62, 4260 (1975).

4. Д.Д Колендрицкий, М.В Курик, Ю.П. Пирятинский, Опт. и спектр. 44, 281 (1978).

5. D.D. Kolendritskii, M.V. Kurik, and Yu.P. Piryatinski, Phys. St. Sol. (b) 91, 741 (1979).

6. M.P. Philpott and J.M. Turlet, J. Chem. Phys. 64, 3852 (1976)

7. R.B. Aust, W.H. Bentlei, and H.G. Drickamer, J. Chem. Pys. 41, 1856 (1964).

8. R. Eiermann, G.M. Parkinson, H. Bassler, and J.M. Thomas, J. Phys. Chem. 87, 544 (1983).

9. C.E. Swenberg, J. Chem. Phys. 51, 1753 (1968).

10. I. Hornyak, J. Luminescence 11, 241 (1975/76).

11. B.A. Brillante and D.P. Craig, Chem. Phys. Lett. 29, 17 (1974).

12. Г.В Сайдов, М.Е. Юдович, Г.Н. Лялин, Опт. и спектр. 46, 707 (1979).

13. Ю.П. Пирятинский, В.Д. Жуков, УФЖ 31, 1197 (1986)

14. Э. Клар, Поличиклические углеводородъ (Химия, Москва, 1971).

15. R. He, N.G. Tassi, B. Blanchet, and A. Pinczuk, Appl. Phys. Lett. 87, 103 (2005).

16. В.М. Агранович, Теория экситонов (Наука, Москва, 1968).

17. Э.А. Силиньш, М.В. Курик, В. Чапек, Электронные прочессы в молекулярных кристаллах: Явления локализачии и поляризации (Зинатне, Рига, 1988).

18. В.Д. Жуков, М.В. Курик, Ю.П. Пирятинский, Л.Н. Цикора, ФТТ 25, 1030 (1983).

19. Ю.П. Пирятинский, ФТТ 31, 208 (1989).
20. P.J. Bounds, W. Siebrand, I. Eisenstein, R.W. Munn, and P. Petelenc, Chem. Phys. 95, 197 (1985).

21. T. Aoki-Matsumoto, K. Furuta, T. Yaada, H. Moriya, K. Mizuno, and A.H. Matsui, Int. J. Mod. Phys. B 15, 3753 (2001).

Одержано 15.07.11

ВЛИЯНИЕ СТРУКТУРНЫХ

ДЕФЕКТОВ НА ЭКСИТОННУЮ

ФОТОЛЮМИНЕСЦЕНЦИЮ ПЕНТАЦЕНА

Ю.П. Пирятинский, М.В. Курик

Р е $з$ ю м е

Исследованы экситонные спектры отражения, поглощения и фотолюминесценции монокристаллов и поликристаллических пленок пентацена в интервале температур 4,2-296 К. Установлено существенное влияние структурных дефектов, которые возникают при фазовых превращениях, на экситонные спектры пентацена. Рассмотрены механизмы возникновения фотолюминесценции в монокристаллах и кристаллических пленках пентацена.

INFLUENCE OF STRUCTURAL DEFECTS ON EXCITONIC PHOTOLUMINESCENCE OF PENTACENE

Yu.P. Piryatinski, M.V. Kurik

Institute of Physics, Nat. Acad. of Sci. of Ukraine (46, Prosp. Nauky, Kyiv 03028, Ukraine)

$\mathrm{S}$ u m m a r y

The exciton reflection, absorption, and photoluminescence spectra for single crystals and polycrystalline films have been studied in the temperature range of 4.2-296 K. A significant influence of structural defects arising during phase transitions on the exciton spectra of pentacene has been detected. The mechanisms of photoluminescence in single crystals and crystalline films of pentacene have been considered. 